JAN DYтко*

\title{
Nadanie pierwszego statutu NIEPUBLICZNEJ SZKOLE WYŻSZEJ
}

\section{Ranga statutu szkoły wyższej}

Statut szkoły wyższej jest podstawowym (obok ustawy z dnia 27 lipca 2005 r. - Prawo o szkolnictwie wyższym ${ }^{1}$ ) aktem prawnym o charakterze normatywnym, regulującym ustrój i funkcjonowanie uczelni. Jest źródłem prawa wewnętrznego. Wyraża autonomię szkoły wyższej, wolność nauki oraz wolność badań naukowych. Nie ogranicza się tylko do roli subsydiarnego aktu prawnego określającego sprawy związane z funkcjonowaniem uczelni, które nie zostały uregulowane $\mathrm{w}$ ustawie, ale jest także aktem określającym specyfikę i tożsamość konkretnej szkoły, jej tradycję i misję ${ }^{2}$. Określa cele uczelni, normuje jej organizację, w tym relacje pomiędzy organami szkoły oraz stosunki prawne tych organów z użytkownikami uczelni.

Na gruncie norm statutowych wyznaczana jest pozycja prawna (określenie praw i obowiązków) różnych podmiotów - studentów, doktorantów, słuchaczy studiów podyplomowych, ale także pracowników uczelni, zarówno naukowo-dydaktycznych, jak i administracyjnych ${ }^{3}$. Statuty zawierają także szczegółowe unormowania będące podstawą indywidualnych rozstrzygnięć o charakterze administracyjnym (np. skreślenie z listy studentów) ${ }^{4}$.

Rangę statutu szkoły wyższej wyznacza wielokrotne odesłanie do jego unormowań w ustawie - Prawo o szkolnictwie wyższym, których charakter jest albo obligatoryjny, albo fakultatywny. Konieczność obowiązywania statu-

* Dr nauk prawnych, Uniwersytet Jana Kochanowskiego w Kielcach.

1 Tj. Dz.U. z 2012 r. poz. 572 z późn. zm., dalej w przypisach: u.p.s.w.

2 D. Dudek, [w:] M. Pyter (red.), Prawo o szkolnictwie wyższym. Komentarz, Warszawa 2012, s. 95 .

${ }^{3}$ J. Korczak, Statut szkoły wyższej w świetle nowych uregulowań prawnych, [w:] A. Szadok-Bratuń (red.), Nowe prawo o szkolnictwie wyższym a podmiotowość studenta, Wrocław 2007, s. 56.

4 Tamże, s. 56-57. 
tu w działalności szkoły wyższej jest bezsporna, aczkolwiek zakres regulacji statutowej jest uwarunkowany zakresem upoważnienia ustawowego.

Przedmiotem niniejszego opracowania jest analiza i wyprowadzenie wniosków ogniskujących się wokół zagadnienia nadania pierwszego statutu niepublicznej szkole wyższej oraz zakresu materii statutowych przekazanych do samodzielnego (aczkolwiek nie dowolnego) uregulowania przez założyciela uczelni, w ramach konstytucyjnie gwarantowanej autonomii szkoły wyższej.

\section{Procedura nadania pierwszego statutu uczelni niepublicznej}

Założycielem uczelni niepublicznej może być osoba fizyczna albo osoba prawna, z wyłączeniem państwowych i samorządowych osób prawnych ${ }^{5}$. Osoba taka, chcąc założyć uczelnię, występuje do ministra właściwego do spraw szkolnictwa wyższego z wnioskiem o wydanie pozwolenia na utworzenie szkoły. Minister wydając takie pozwolenie, określa założyciela uczelni, jej nazwę, siedzibę, prowadzone kierunki studiów i poziom kształcenia, a także minimalną wielkość i rodzaj środków majątkowych, które założyciel jest obowiązany przeznaczyć na jej utworzenie i funkcjonowanie, przy czym wysokość środków finansowych nie może być niższa niż 500 tys. zł. Pozwolenie na utworzenie uczelni niepublicznej wydawane jest na czas nieokreślony $^{6}$. Po jego uzyskaniu założyciel składa $\mathrm{w}$ formie aktu notarialnego oświadczenie woli o założeniu uczelni niepublicznej (tzw. akt założycielski), który określa w szczególności założyciela, nazwę, siedzibę i szczegółowy zakres działalności uczelni, wielkość środków majątkowych przeznaczonych na utworzenie uczelni, w tym wartość rzeczy przekazanych jej na własność, termin ich przekazania oraz sposób dalszego finansowania uczelni ${ }^{7}$. $Z$ chwilą uzyskania przez uczelnię osobowości prawnej (co następuje z chwilą wpisania jej do rejestru uczelni niepublicznych ${ }^{8}$ ) uniezależnia się ona od swojego założyciela, który posiada tylko takie uprawnienia względem założonej przez siebie szkoły, jakie określone są w jej statucie ${ }^{9}$.

Pierwszy statut uczelni niepublicznej zawsze nadaje jej założyciel ${ }^{10}$. Nadanie pierwszego statutu winno być poprzedzone uzyskaniem opinii związków

\footnotetext{
${ }^{5}$ Art. 2 ust. 1 pkt 3 i 4 u.p.s.w.

6 Art. 20 ust. 1-2 oraz ust. 3 i 8 u.p.s.w.

7 Art. 23 ust. 1 u.p.s.w.

8 Art. 29 ust. 1 u.p.s.w.

9 H. Izdebski, J.M. Zieliński, Prawo o szkolnictwie wyższym. Komentarz, Warszawa 2015, s. 108. Zob. także wyrok NSA z dnia 3 sierpnia 2016 r., I OSK 3484/15, LEX Nr 2100717.

${ }^{10}$ Art. 24 ust. 1 u.p.s.w.
} 
zawodowych działających w uczelni, które przedstawiają taką opinię w terminie 30 dni ${ }^{11}$. Przyjmuje się, że udział związków zawodowych w redagowaniu statutu uczelni niepublicznej ma na celu podkreślenie znaczenia jej autonomii $^{12}$. Jednakże bezskuteczny upływ terminu na zajęcie stanowiska związków zawodowych w tej sprawie skutkuje uznaniem, że wymóg zasięgnięcia opinii uznaje się za zachowany ${ }^{13}$.

Nadanie pierwszego statutu przez założyciela stanowi logiczną konsekwencję tego, że na etapie organizacyjnym (kiedy uczelnia dopiero się konstytuuje) nie ma jeszcze organów, które mogłyby uchwalić statut ${ }^{14}$. W późniejszym okresie założyciel uczelni zazwyczaj powierza organowi kolegialnemu (określonemu w pierwszym statucie) kompetencję do wprowadzania zmian statutowych, a nawet przyjęcia nowego albo kolejnych statutów ${ }^{15}$.

Statut niepublicznej szkoły wyższej powinien stanowić bezpośrednią treść aktu ustanawiającego statut ${ }^{16}$. Zgodnie z nomenklaturą przyjętą w ustawie - Prawo o szkolnictwie wyższym akt taki nazwany został decyzją, aczkolwiek nie można go sytuować w kręgu decyzji administracyjnych, gdyż nie stanowi władczego objawu woli organu administracyjnego czy administrującego. W takiej bowiem roli założyciel uczelni niepublicznej nie występuje ${ }^{17}$.

Decyzja w sprawie nadania statutu niepublicznej szkole wyższej powinna przede wszystkim zawierać wskazanie podstawy prawnej upoważniającej założyciela do podjęcia tego typu aktu. W podstawie takiej winny być przywołane przepisy określające właściwość założyciela do nadania pierwszego statutu oraz wskazane materie statutowe pozostające do unormowania w tej formie, zwłaszcza te materie, których unormowanie jest obligatoryjne ${ }^{18}$.

Pierwszy statut uczelni niepublicznej wchodzi w życie z dniem określonym w decyzji założyciela ${ }^{19}$. Ponieważ nie jest to akt o charakterze powszechnie obowiązującym, nie podlega regułom promulgacji określonym w ustawie z dnia 20 lipca 2000 r. o ogłaszaniu aktów normatywnych i niektórych innych aktów prawnych ${ }^{20}$.

11 Art. 58 ust. 1 i 1 a u.p.s.w.

12 M. Lenard, [w:] W. Sanetra, M. Wierzbowski (red.), Prawo o szkolnictwie wyższym. Komentarz, Warszawa 2013, s. 131.

${ }^{13}$ Art. 58 ust. $1 b$ u.p.s.w.

${ }^{14}$ D. Dudek, [w:] M. Pyter (red.), Prawo o szkolnictwie..., s. 100.

15 J. Korczak, Korczak, Statut szkoły..., s. 55-56.

16 Tamże, s. 72.

17 Tamże.

18 Tamże, s. 73.

19 Art. 58 ust. 4 u.p.s.w.

20 Tj. Dz.U. z 2016 r. poz. 296. 


\section{Materie statutowe}

Założyciel uczelni niepublicznej może podejmować decyzje dotyczące szkoły wyższej tylko w przypadkach określonych przez statut, który jej nadał ${ }^{21}$. Mając tak silne uprawnienie, może przyznać sobie szczególne prerogatywy związane z funkcjonowaniem szkoły, choć oczy wiście nie mogą one wykraczać poza upoważnienia wynikające z ustawy - Prawo o szkolnictwie wyższym, ale też naruszać przepisów innych ustaw ${ }^{22}$.

Materie, które ustawodawca pozostawił do regulacji statutowej, są zróżnicowane zarówno co do rangi, jak i ich przedmiotu. Część z nich ma na celu dopełnienie ogólnych norm ustawowych, inne wyłączają regulację ustawową na rzecz statutu (jako przejaw autonomii statutowej). W tym wypadku ustawodawca formułuje dyrektywę: ,jeżeli statut nie stanowi inaczej". Taka dyrektywa stwarza podstawy do przyjęcia pierwotnego stanu regulacji ${ }^{23}$, a zatem takiego stanu, $\mathrm{w}$ którym normy statutowe nie są traktowane jako pochodne względem norm ustawowych. Stąd mogą być bezpośrednim źródłem praw i obowiązków podmiotów będących użytkownikami uczelni czy też jej pracownikami (była o tym mowa w początkowych fragmentach opracowania).

W niepublicznej szkole wyższej materie statutowe zasadniczo dotyczą kilku kategorii przedmiotowych. Obejmują one: 1) zagadnienia ustrojowe szkoły; 2) sprawy personalne; 3) zagadnienia mające związek z działalnością badawczą uczelni; 4) sprawy finansowe ${ }^{24}$.

\subsection{Ustrój uczelni}

O ustroju szkoły wyższej świadczy przede wszystkim usytuowanie jej organów oraz ich relacje między sobą. Przyjmuje się, że kreowanie struktur organizacyjnych w uczelniach niepublicznych doznaje większej swobody aniżeli w uczelniach publicznych, co z oczywistych względów wydaje się w pełni uzasadnione. Należy mieć też na uwadze, że budowanie struktur uczelni (zarówno publicznych, jak i niepublicznych) powinno być oceniane pod względem prakseologicznym - kiedy to uczelnia będzie zorientowana na efektywne osiąganie swoich celów, biorą pod uwagę jej społeczne oto-

\footnotetext{
21 Art. 24 ust. 3 u.p.s.w.

22 Por. H. Izdebski, J.M. Zieliński, Prawo o szkolnictwie..., s. 108.

23 J. Korczak, Statut szkoły..., s. 59.

24 Tamże, s. 61.
} 
czenie (środowisko, w którym funkcjonuje), a także sam charakter szkoły (np. akademicki czy zawodowy) oraz jej misję ${ }^{25}$.

Statut uczelni niepublicznej określa, jakie organy o charakterze kolegialnym występują $w$ takiej uczelni ${ }^{26}$. Regulacją statutową objęty jest także tryb pracy tych organów oraz zasady zwoływania ich posiedzeńn ${ }^{27}$. Unormowania w tym zakresie powinny cechować się odpowiednim stopniem szczegółowości. W doktrynie prawa podkreśla się, że postanowienia statutu - w zakresie trybu pracy organów kolegialnych, mają w pełni autonomiczny charakter i nie są związane regułami wyznaczonymi przez ustawę ${ }^{28}$. Można zatem uznać za dopuszczalne następujące formy zwoływania posiedzeń organów kolegialnych: 1) wiadomość przesłana pocztą głosową czy sms-em w telefonii komórkowej; 2) pocztą elektroniczną za pośrednictwem Internetu; 3) drogą telefoniczną. Jednakże prawo użycia każdej z tych form musi być wyraźnie przewidziane przez statut, a ciężar udowodnienia skuteczności zawiadomienia o posiedzeniu spoczywa na osobie, która z przewidzianej formy korzysta. Statut powinien także określać skutki nieprawidłowego zawiadomienia o posiedzeniu organu kolegialnego, jeżeli owa nieprawidłowość uniemożliwiła wzięcie udziału w posiedzeniu określonej osobie, jednakże bez jej winy. Może być to np. odwołanie posiedzenia i wyznaczenie innego terminu jego odbycia poprzedzonego prawidłową procedurą powiadomienia wszystkich zainteresowanych.

W relacjach między organami uczelni niepublicznej statut może modyfikować albo nawet wykluczać ustawową procedurę zawieszania wykonania uchwał senatu przez rektora ${ }^{29}$. Modyfikacja może iść w kierunku np. wydłużenia terminu, w jakim rektor zawiesza wykonanie uchwały, albo zmiany kwalifikowanej większości koniecznej do odrzucenia veta rektora i tym sposobem wejścia uchwały $\mathrm{w}$ życie. Jeżeli jednak statut nie przewiduje $\mathrm{w}$ tym zakresie żadnych zmian, powinno być to ujęte bezpośrednio w nim - jako opowiedzenie się przez założyciela za utrzymaniem regulacji ustawowych ${ }^{30}$.

Materią statutową o charakterze ustrojowym w uczelni niepublicznej jest wskazanie innego oprócz rektora organu jednoosobowego ${ }^{31}$. Coraz częściej organem takim jest „prezydent” uczelni, któremu statut przyznaje określone kompetencje, aczkolwiek nie muszą się one ograniczać, i zwykle nie ograniczają się, do charakteru honorowego ${ }^{32}$. Nie jest też wykluczone, że

\footnotetext{
${ }^{25}$ Por. P. Orzeszko, [w:] W. Sanetra, M. Wierzbowski, Prawo o szkolnictwie..., s. 133.

26 Art. 60 ust. 5 u.p.s.w.

27 Art. 69 ust. 1 u.p.s.w.

28 Por. P. Orzeszko, [w:] W. Sanetra, M. Wierzbowski, Prawo o szkolnictwie..., s. 145.

29 Art. 65 ust. 4 w związku z ust. 2 i 3 u.p.s.w.

${ }^{30}$ H. Izdebski, J.M. Zieliński, Prawo o szkolnictwie..., s. 227.

31 Art. 60 ust. 7 u.p.s.w.

${ }^{32}$ H. Izdebski, J.M. Zieliński, Prawo o szkolnictwie..., s. 217.
} 
poza rektorem - organem jednoosobowym może być nawet sam założyciel, oczywiście jeżeli jest osobą fizyczną ${ }^{33}$. Statut uczelni niepublicznej normuje także powoływanie i odwoływanie innych organów jednoosobowych oraz ich zastępców przez założyciela. Statutowo założyciel może być wyłączony z tego uprawnienia, choćby na rzecz rektora, który w przypadku powoływania organów jednoosobowych i ich zastępców związany jest wymogiem zasięgnięcia opinii senatu uczelni ${ }^{34}$. Niezależnie od tego, kto będzie powoływał i odwoływał organy jednoosobowe oraz ich zastępców, statut powinien normować tryb przeprowadzenia tej procedury ${ }^{35}$. Należy wszakże zauważyć, iż powołania czy odwołania organów jednoosobowych oraz ich zastępców nie można traktować $w$ kategoriach nawiązania lub rozwiązania stosunku pracy, natomiast jest to $\mathrm{w}$ istocie powierzenie sprawowania określonej funkcji w uczelni ${ }^{36}$. Mogą one dotyczyć np. podejmowania decyzji dotyczących majątku uczelni, w tym uprawnień do zbycia lub obciążenia mienia szkoły. Organ jednoosobowy może również nabyć z mocy statutu uprawnienia do sprawowania nadzoru nad administracją uczelni ${ }^{37}$. Nadzór ten będzie jednak zdeterminowany regulaminem działania uczelnianej administracji, który podobnie jak statut nadawany jest przez założyciela lub przez organ wskazany w statucie ${ }^{38}$. Regulaminy, jako akty prawa wewnętrznego - w hierarchii usytuowane niżej od statutów, w zasadzie będą ograniczały się tylko do wskazania ogólnych zakresów działania poszczególnych jednostek administracyjnych uczelni (np. kadr, kwestury, komórki inwestycji i remontów) ${ }^{39}$.

W ustroju uczelni niepublicznej mieści się także struktura organizacyjna szkoły - zwłaszcza określenie jej podstawowych jednostek organizacyjnych. Jednostkę taką niekoniecznie musi tworzyć wydział. Statut może bowiem przewidywać inną niż wydział jednostkę o takim charakterze. Jednakże aby jednostka taka posiadała status równy wydziałowi, musi mieć minimum następujących uprawnień: 1) prowadzenie co najmniej jednego kierunku studiów; 2) prowadzenie studiów doktoranckich albo alternatywnie prowadzenie badań $\mathrm{w}$ co najmniej $\mathrm{w}$ jednej $\mathrm{z}$ dyscyplin naukowych ${ }^{40}$.

Z wydzieleniem w uczelni podstawowych jednostek organizacyjny łączy się także statutowe określenie ich organów kolegialnych (np. rad wydziału, rad instytutu) wraz trybem wyboru członków tych organów i procentowej partycypacji $w$ ich składzie przedstawicieli nauczycieli akademickich, przed-

\footnotetext{
33 Por. P. Orzeszko, [w:] W. Sanetra, M. Wierzbowski, Prawo o szkolnictwie..., s. 134.

${ }^{34}$ Art. 80 ust. 1 u.p.s.w.

35 Art. 80 ust. 2 u.p.s.w.

36 Por. wyrok SN z dnia 6 września 2005 r., I PK 58/05, OSN 2006, nr 13-14, poz. 205.

37 Art. 66 ust. 6 u.p.s.w.

38 Art. 83 ust. 2 u.p.s.w.

39 P. Orzeszko, M. Lenard, [w:] W. Sanetra, M. Wierzbowski, Prawo o szkolnictwie..., s. 158.

${ }^{40}$ Art. 2 ust. 1 pkt 29 u.p.s.w.
} 
stawicieli doktorantów i studentów oraz przedstawicieli pracowników niebędących nauczycielami akademickimi ${ }^{41}$. Procentowa partycypacja poszczególnych grup wchodzących w skład organu kolegialnego podstawowej jednostki organizacyjnej powinna być dostosowana do aktualnego stanu osobowego tej jednostki, istniejącego w dniu ogłoszenia wyborów do jej organu. W wielu uczelniach utrzymuje się jednak tradycja zapewnienia obecności $\mathrm{w}$ radach podstawowych jednostek organizacyjnych tych profesorów, którzy z racji wieku utracili już prawa wyborcze. Tradycja ta warta jest wszakże podtrzymania, niezależnie od zróżnicowanego statusu tych profesorów, względem czynnych członków organu kolegialnego ${ }^{42}$.

Szczegółowe kompetencje rad podstawowych jednostek organizacyjnych są również normowane statutem, aczkolwiek statut nie musi w jednym miejscu swego tekstu zawierać całego wykazu wszystkich kompetencji tych rad. Mogą być one rozproszone $w$ różnych miejscach statutu, chociaż pożądane byłoby (ze względów choćby praktycznych), aby przynajmniej większość tych kompetencji była zamieszczona np. $\mathrm{w}$ jednym rozdziale statutu albo $\mathrm{w}$ innej redakcyjnie wydzielonej jego części ${ }^{43}$. Adekwatnie należałoby ująć kompetencje kierownika podstawowej jednostki organizacyjnej (np. dziekana wydziału czy dyrektora instytutu), które również są normowane statutowo ${ }^{44}$. Kompetencje te nie mogą się jednak krzyżować z kompetencjami rady jednostki czy innych organów uczelni (np. kompetencjami rektora). Statut musi tu bowiem uwzględniać ustawową zasadę zastrzeżenia kompetencji na rzecz określonych organów uczelni ${ }^{45}$.

Osobliwą materią statutową o charakterze ustrojowym w niepublicznej szkole wyższej są tzw. sytuacje kryzysowe (nadzwyczajne), wynikające z różnych okoliczności, czasami mających charakter nagłego i niespodziewanego zdarzenia (np. śmierć założyciela) ${ }^{46}$. W przypadku wystąpienia takiej okoliczności statut musi normatywnie zabezpieczać sposób przejęcia jego funkcji (kto i jakie funkcje przejmuje). Wymaga to jednak akceptacji (zgody) ministra właściwego do spraw szkolnictwa wyższego wyrażonej w formie decyzji administracyjnej ${ }^{47}$. Jeżeli założycielem uczelni niepublicznej jest osoba prawna, statut musi z kolei regulować procedurę jej likwidacji. Jest to proces rozdysponowania majątkiem szkoły, po zaspokojeniu roszczeń wierzycieli, w szczególności zaś pracowników i studentów. Majątek pozostały po takim

\footnotetext{
41 Art. 67 ust. 1 i 3 u.p.s.w.

42 P. Orzeszko, [w:] W. Sanetra, M. Wierzbowski, Prawo o szkolnictwie..., s. 142-143.

${ }^{43}$ H. Izdebski, J.M. Zieliński, Prawo o szkolnictwie..., s. 232.

44 Art. 68 ust. 2 i art. 70 ust. 1 u.p.s.w.

45 Por. P. Orzeszko, [w:] W. Sanetra, M. Wierzbowski, Prawo o szkolnictwie..., s. 146.

46 Por. D. Dudek, [w:] M. Pyter (red.), Prawo o szkolnictwie..., s. 100.

${ }^{47}$ Art. 58 ust. 2 u.p.s.w.
} 
zaspokojeniu powinien być przeznaczony na cele określone w statucie ${ }^{48}$. Statut uczelni niepublicznej reguluje również szczegółowy tryb przeprowadzenia czynności likwidacyjnych oraz tryb powołania osoby likwidatora ${ }^{49}$. $\mathrm{Z}$ dniem zakończenia likwidacji następuje wykreślenie uczelni z rejestru szkół wyższych niepublicznych. Tym sposobem uczelnia traci osobowość prawną, a jej byt prawny ustaje ${ }^{50}$.

\subsection{Sprawy personalne}

Trybunał Konstytucyjny w wyroku z dnia 28 kwietnia 2009 r. ${ }^{51}$ stwierdził, że statut uczelni niepublicznej może regulować więcej kwestii decydujących o treści stosunku pracy niż statut uczelni publicznej. Przykładowo może określać tryb nawiązania i rozwiązania stosunku pracy z nauczycielem akademickim. Postanowienia statutu uczelni niepublicznej mogą znosić ustawowe kompetencje ministra właściwego do spraw szkolnictwa wyższego w zakresie mianowania na stanowisko profesora zwyczajnego lub profesora nadzwyczajnego osoby pełniącej funkcję rektora szkoły wyższej niepublicznej ${ }^{52}$. Co więcej, przepisy statutu uczelni niepublicznej mogą w ogóle wyłączać nawiązywanie stosunków pracy z nauczycielami akademickimi na podstawie mianowania, a przewidywać w tym zakresie tylko zawieranie umów o pracę ${ }^{53}$. Umowy takie mogą być zawierane przez organ uczelni wskazany w statucie ${ }^{54}$. Takiej swobody nie ma natomiast w przypadku uczelni publicznych, w której tylko rektor jest uprawniony do nawiązania czy rozwiązania stosunku pracy z nauczycielem akademickim i uprawnienia tego nie może scedować na inny organ (np. wskazany w statucie albo w zatwierdzonym przez rektora podziale czynności) ${ }^{55}$. Statut uczelni niepublicznej może również wyłączyć rektora (na rzecz innego organu uczelni), który będzie uprawniony do nawiązywania stosunku pracy $\mathrm{w}$ formie umowy $\mathrm{z}$ pracownikami niebędącymi nauczycielami akademickimi ${ }^{56}$. Statut może do takich osób zaliczyć np. kanclerza ${ }^{57}$. Wyłączenie może także dotyczyć senatu uczelni niepublicznej, który na mocy statutu może być pozbawiony na rzecz innego organu (tu

\footnotetext{
48 Art. 27 ust. 1-2 u.p.s.w.

49 Art. 27 ust. 8 i ust. 3 u.p.s.w.

${ }^{50}$ H. Izdebski, J.M. Zieliński, Prawo o szkolnictwie..., s. 117.

${ }^{51}$ K 27/07, Dz.U. z 2009 r. Nr 68, poz. 584.

52 Art. 121 ust. $4-5$ u.p.s.w.

${ }^{53}$ H. Izdebski, J.M. Zieliński, Prawo o szkolnictwie..., s. 368.

${ }^{54}$ Art. 118 ust. 3 u.p.s.w.

55 Wyrok SN z dnia 11 kwietnia 2013 r., I PK 259/12, OSN 2014, nr 2, poz. 22.

56 Art. 135 ust. 1 u.p.s.w.

57 H. Izdebski, J.M. Zieliński, Prawo o szkolnictwie..., s. 409.
} 
również w grę może wchodzić kanclerz) prawa do ustalania trybu udzielania urlopów wypoczynkowych nauczycieli akademickich ${ }^{58}$. W doktrynie prawa przyjmuje się, że ów tryb zasadniczo będzie eliminował reguły planowania urlopów czy też udzielenie urlopu na tzw. żądanie (regulacje w tym zakresie zawarte są w ustawie z dnia 26 czerwca 1974 r. - Kodeks pracy ${ }^{59}$ ), chyba że organ wskazany w statucie uczelni niepublicznej odwoła się w tym zakresie do rozwiązań kodeksowych ${ }^{60}$.

Odrębna (w stosunku do ustawowej) regulacja statutowa w niepublicznej szkole wyższej może dotyczyć także takich zagadnień związanych z zatrudnieniem, jak: 1) możliwość dodatkowego zatrudnienia nauczyciela akademickiego $\mathrm{w}$ ramach stosunku pracy $\mathrm{u}$ pracodawcy prowadzącego działalność dydaktyczną lub naukowo-badawczą; 2) wskazania przyczyn odmowy wyrażenia zgody przez rektora na dodatkowe zatrudnienie nauczyciela akademickiego; 3) obowiązku informowania rektora o prowadzeniu przez nauczyciela akademickiego działalności gospodarczej; 4) wskazania trybu wypowiedzenia przez rektora stosunku pracy nauczycielowi akademickiemu w przypadku kontynuowania dodatkowego zatrudnienia bez zgody rektora - jeżeli zgoda taka była wymagana ${ }^{61}$.

Odrębność statutowa może jeszcze głębiej sięgać w stosunek pracy w uczelni niepublicznej, albowiem w statucie mogą być przewidziane inne niż w ustawie wymiary zajęć dydaktycznych nauczycieli akademickich oraz wymiary czasu pracy bibliotekarzy, pracowników dokumentacji, a także pracowników informacji naukowej ${ }^{62}$. W doktrynie prawa zauważa się, że statutowy wymiar zajęć dydaktycznych nauczycieli akademickich, jak i wymiar czasu pracy bibliotekarzy, pracowników dokumentacji i informacji naukowej nie powinien jednak wykraczać poza ramy ustawowe ${ }^{63}$. Oczywiście chodzi o wykroczenie polegające na zwiększeniu tego wymiaru, albowiem zgodnie z art. 66 ust. 2 Konstytucji Rzeczypospolitej Polskiej z dnia 2 kwietnia 1997 r. ${ }^{64}$ maksymalne normy czasu pracy wyznacza tylko ustawa, a nie akt niższego rzędu - zwłaszcza akt niemający waloru powszechnie obowiązującego, jakim jest statut szkoły wyższej.

Analizując materie statutowe obejmujące sprawy personalne w uczelni niepublicznej, nie sposób pominąć tych regulacji, które odnoszą się do ogólnie przyjętej zasady zakazu łączenia funkcji czy stanowisk. Ustawa uprawnia założyciela do ustanowienia w statucie zakazu łączenia funkcji członka or-

\footnotetext{
${ }^{58}$ Art. 133 ust. 7 u.p.s.w.

59 Tj. Dz.U. z 2016 r., poz. 1666.

60 W. Sanetra, [w:] W. Sanetra, M. Wierzbowski, Prawo o szkolnictwie..., s. 303.

${ }^{61}$ Art. 129 ust. 11 u.p.s.w.

${ }^{62}$ Art. 130 ust. 8 u.p.s.w.

${ }^{63}$ W. Sanetra, [w:] W. Sanetra, M. Wierzbowski, Prawo o szkolnictwie..., s. 298.

${ }^{64}$ Dz.U. Nr 78, poz. 483 z późn. zm.
} 
ganu kolegialnego uczelni z funkcją organu jednoosobowego innej uczelni, ponadto ze statusem założyciela innej uczelni niepublicznej będącego osobą fizyczną lub ze statusem członka organu osoby prawnej będącej założycielem innej uczelni niepublicznej ${ }^{65}$. W praktyce chodzi też o zakazy łączenia stanowisk jednoosobowych - rektora lub prorektora albo dziekana i prodziekana $\mathrm{w}$ dwóch różnych uczelniach. Podobnie rektor jednej uczelni nie może być kierownikiem podstawowej jednostki organizacyjnej $w$ innej uczelni ${ }^{66}$.

Naruszenie zakazu łączenia funkcji i stanowisk nie jest sankcjonowane ustawowo, stąd należy przyjąć, że regulacje w tym zakresie powinny znaleźć się w statucie. Statutowym skutkiem złamania owego zakazu mogłoby być wygaśnięcie mandatu organu jednoosobowego w innej uczelni bądź ustaniem członkostwa w organie osoby prawnej będącej założycielem innej uczelni niepublicznej. Wzorem takiej regulacji może być przepis art. 129 ust. 7 ustawy - Prawo o szkolnictwie wyższym, który stanowi, że skutkiem niezaprzestania kontynuowania dodatkowego zatrudnienia przez nauczyciela akademickiego będącego jednocześnie organem jednoosobowym uczelni publicznej (w razie braku zgody właściwego organu kolegialnego) jest wygaśnięcie mandatu organu jednoosobowego.

\subsection{Działalność naukowa}

Materią statutową w uczelni niepublicznej, która podlega pośredniemu unormowaniu w statucie, jest dysponowanie (zarządzanie) prawami autorskimi i prawami pokrewnymi oraz prawami własności przemysłowej oraz określenie zasad komercjalizacji tych praw. Jest to obszar działalności naukowej uczelni. Wprawdzie statut nie reguluje wprost tych zagadnień, jednakże wskazuje organ uprawniony do uchwalenia w tym względzie regulaminu normującego przede wszystkim: 1) prawa i obowiązki uczelni, pracowników oraz studentów i doktorantów w zakresie ochrony i korzystania z praw autorskich i praw pokrewnych oraz praw własności przemysłowej; 2) zasady wynagradzania twórców; 3) zasady i procedury komercjalizacji wyników badań; 4) zasady korzystania z majątku uczelni wykorzystywanego do komercjalizacji oraz świadczenia usług naukowo-badawczych ${ }^{67}$. Prawidłowość opracowania regulaminu w powyższych kwestiach wymaga uprzedniego zapoznania się przez stanowiącego taki regulamin z prawem własności przemysłowej (ustawa z dnia 30 czerwca 2000 r. - Prawo własności przemysłowej ${ }^{68}$ ), a także

\footnotetext{
${ }^{65}$ Art. 79 ust. 2 u.p.s.w.

${ }^{66}$ H. Izdebski, J.M. Zieliński, Prawo o szkolnictwie..., s. 254.

67 Art. 86c ust. 1 u.p.s.w.

68 Tj. Dz.U. z 2013 r. poz. 1410 z późn. zm.
} 
ustawą z dnia 4 lutego $1994 \mathrm{r}$. o prawie autorskim i prawach pokrewnych ${ }^{69}$. W przypadku uczelni rolniczych w grę będą wchodziły także przepisy ustawy z dnia 26 czerwca 2003 r. o ochronie prawnej odmian roślin ${ }^{70}$. Wszelkie regulaminy jako akty prawa wewnętrznego muszą przejawiać pełną zgodność z prawem powszechnie obowiązującym ${ }^{71}$. $Z$ hierarchii wewnętrznych aktów prawnych wynika także konieczności zgodności regulaminów w uczelni z jej statutem.

Regulaminem uchwalonym przez organ wskazany w statucie uczelni niepublicznej objęte będą także zasady korzystania z infrastruktury badawczej uczelni, ze szczególnym uwzględnieniem: 1) praw i obowiązków uczelni oraz jej pracowników, doktorantów lub studentów w zakresie korzystania z infrastruktury badawczej przy prowadzeniu badań naukowych lub prac rozwojowych; 2) zasad korzystania i odpłatności za udostępnianie przez uczelnię infrastruktury badawczej innym podmiotom spoza uczelni - w celu prowadzenia przez te podmioty badań naukowych albo prac rozwojowych ${ }^{72}$.

W obszarze spraw związanych z działalnością naukową w niepublicznej szkole wyższej znajduje się tzw. centrum transferu technologii czy inkubator przedsiębiorczości (chodzi o wsparcie działalności gospodarczej środowiska akademickiego). Są to jednostki organizacyjne o charakterze ogólnouczelnianym (zatem niezależne od wydziałów czy instytutów), a ich działalność jest pośrednio regulowana statutowo. Organ wskazany w statucie uczelni zatwierdza bowiem regulamin działania takiej jednostki ${ }^{73}$. Co więcej, statut uczelni wskazuje także na organ uprawniony do zatrudnienia dyrektora akademickiego inkubatora przedsiębiorczości albo dyrektora centrum transferu technologii. Kandydaci na takich dyrektorów rekrutują się spośród osób przedstawionych przez rady nadzorujące inkubator lub centrum ${ }^{74}$. Rady takie składają się zazwyczaj z przedstawicieli uczelni oraz jednostek samorządu terytorialnego ( $w$ miejscu usytuowania uczelni), a także przedstawicieli korporacji publicznoprawnych (samorząd gospodarczy, zawodowy) związanych miejscowo z działalnością szkoły.

\footnotetext{
69 Tj. Dz.U. z 2016 r. poz. 666.

70 Tj. Dz.U. z 2016 r. poz. 843.

71 Por. H. Izdebski, J.M. Zieliński, Prawo o szkolnictwie..., s. 279.

72 Art. 86 c ust. 1 u.p.s.w.

73 Art. 86 ust. 5 u.p.s.w.

74 Art. 86 ust. 7 u.p.s.w.
} 


\subsection{Sprawy finansowe}

Każda uczelnia, niezależnie od tytułu utworzenia, charakteru i profilu kształcenia, prowadzi samodzielną gospodarkę finansową ${ }^{75}$. W uczelni niepublicznej, która nie jest jednostką sektora finansów publicznych, statut określa organ kolegialny, który zatwierdza plan rzeczowo-finansowy działalności takiej uczelni, będący podstawą prowadzenia przez szkołę gospodarki finansowej ${ }^{76}$. W planie takim (z uwagi na charakter uczelni niepublicznej) na czoło wysuwają się zasady pobierania i wysokość opłat za świadczone usługi edukacyjne. Statut uczelni niepublicznej wskazuje organ, który określa takie zasady, jednakże ustawowym ograniczeniem tej regulacji jest niemożność wprowadzenia takich opłat, które przekraczałyby koszty ponoszone $\mathrm{w}$ niezbędnym zakresie do uruchomienia i prowadzenia $\mathrm{w}$ danej uczelni, odpowiednio: studiów lub studiów doktoranckich oraz zajęć na studiach lub studiach doktoranckich. Wysokość opłat związanych z powtarzaniem określonych zajęć na studiach lub studiach doktoranckich również musi uwzględniać nieprzekraczalność kosztów, o jakich mowa wyżej ${ }^{77}$.

Statutową materią o charakterze finansowym w niepublicznej szkole wyższej jest także wskazanie organu, który określi wzór umowy pomiędzy uczelnią a studentem lub osobą przyjętą na studia w zakresie wysokości i warunków pobierania opłat związanych z odbywaniem studiów oraz wnoszeniem opłat za usługi edukacyjne ${ }^{78}$. Należy jednak pamiętać, że wzór umowy pomiędzy uczelnią niepubliczną a jej studentem nie może naruszać interesów studenta - jako konsumenta usług dydaktycznych oferowanych przez uczelnię, jeśli wzór taki wprowadzałby dysproporcję w prawach i obowiązkach na niekorzyść studenta. Równowaga stosunku obligacyjnego jest w tym wypadku wartością nadrzędną79.

\section{Konkluzje}

Silnym przejawem gwarantowanej Konstytucją autonomii uczelni (zarówno publicznej, jak i niepublicznej) jest jej statut. Ustawa zasadnicza, a w dalszej konsekwencji ustawa - Prawo o szkolnictwie wyższym, poprzez przyznaną szkole autonomię zabezpieczają jej samodzielność i niezależność,

75 Art. 100 ust. 2 u.p.s.w.

76 Art. 100 ust. 2a u.p.s.w.

77 Art. 99 ust. 4 u.p.s.w.

78 Art. 160a ust. 5 u.p.s.w.

79 Por. wyrok SA w Warszawie z dnia 27 października 2008 r., VI ACa 654/08, waw. sa.gov.pl. 
przede wszystkim w obszarze ustrojowym. O ustroju uczelni świadczy jej statut, stąd często używa się w tym kontekście - dla ukazania rangi statutu, pojęcia autonomii statutowej. Autonomia taka nie jest jednak nieograniczona, albowiem jej zakres wynika z zasięgu upoważnienia ustawowego do statutowego uregulowania tych materii, których ustawa sama nie normuje bądź normuje je w sposób niewyczerpujący. Statut dopełnia więc ustawę, bez jego unormowań uczelnia nie mogłaby normalnie funkcjonować - realizować swoich celów i wypełniać swojej misji.

Z hierarchicznej budowy systemu źródeł prawa wynika, że statut jako akt prawa wewnętrznego jest podporządkowany ustawie. Stąd regulacje statutowe nie tylko mają za podstawę ustawę, ale także nie mogą być z nią sprzeczne, co więcej, nie mogą normować więcej aniżeli tyle, na ile pozwala im ustawa. Same przepisy statutu muszą być spójne, wewnętrznie niesprzeczne, nie normować tego, co już zostało unormowane w innymi miejscu tego aktu. Przy konstruowaniu statutu można posiłkować się zasadami techniki prawodawczej, które umożliwiają właściwe zredagowanie tekstu prawnego, z uwzględnieniem jego podziału na części, rozdziały, podrozdziały i mniejsze jednostki redakcyjne, łącznie z paragrafami, punktami i podpunktami. Zasady techniki prawodawczej umożliwiają stworzenie przejrzystego i komunikatywnego aktu, zrozumiałego dla wielu odbiorców jego norm. W przypadku szkoły wyższej zakres odbiorców norm statutowych jest stosunkowo szeroki, albowiem obejmuje grupy pracowników naukowych, pracowników administracji oraz studentów i doktorantów, a czasami także osoby z otoczenia zewnętrznego uczelni. Można postulować de lege ferenda, aby w ustawie - Prawo o szkolnictwie wyższym wprowadzono stosowny przepis zalecający korzystanie przez założyciela uczelni niepublicznej (choć powinno mieć to swoje odniesienie również do szkół publicznych) z rozporządzenia Prezesa Rady Ministrów z dnia 20 czerwca 2002 r. w sprawie „Zasad Techniki Prawodawczej"80.

Wielokrotność ustawowych odesłań do statutu jest wyrazem nie tylko daleko idącej statutowej autonomii uczelni, ale świadczy również o przekonaniu ustawodawcy, które może być traktowane w kategoriach swoistego zaufania, że w określonych sprawach szkoła sama potrafi wybrać optymalny dla siebie wariant funkcjonowania, struktury organizacyjnej czy rozwiązań personalnych, biorąc pod uwagę np. takie czynniki, jak specyfika szkoły, jej potencjał naukowy czy też infrastruktura badawcza. Założyciel uczelni niepublicznej - konstruując i wprowadzając pierwszy statut szkoły, musi mieć jednakże na uwadze, że zakres przyznanej autonomii w kreowaniu statutu doznaje ograniczenia zasadą legalizmu, sankcjonowaną aktem nadzoru ministra właściwego do spraw szkolnictwa wyższego, który w razie, gdy

80 Tj. Dz.U. z 2016 r. poz. 283. 
statut narusza prawo - może orzec o jego nieważności ${ }^{81}$. Swoistym atutem tej sankcji jest to, że jej zastosowanie będzie w istocie uwalniało założyciela uczelni niepublicznej, ale także jej organy oraz pracowników i studentów (doktorantów), od ryzyka działań na podstawie wadliwego statutu. Ryzyko takie może nieść ze sobą powstanie skutków prawnych - trudnych bądź nawet czasami niemożliwych do odwrócenia. W uczelni niepublicznej ma to niebagatelne znaczenie, choćby ze względu na to, że stosunek prawny łączący taką uczelnię z jej użytkownikiem ma charakter zobowiązaniowy.

Słowa kluczowe: niepubliczna szkoła wyższa, statut, materie statutowe.

\section{Bibliografia}

Izdebski H., Zieliński J.M., Prawo o szkolnictwie wyższym. Komentarz, Warszawa 2015. Pyter M. (red.), Prawo o szkolnictwie wyższym. Komentarz, Warszawa 2012.

Sanetra W., Wierzbowski M. (red.), Prawo o szkolnictwie wyższym. Komentarz, Warszawa 2013.

Szadok-Bratun A. (red.), Nowe prawo o szkolnictwie wyższym a podmiotowość studenta, Wrocław 2007.

\section{BESTOWAL OF THE FIRST STATUTES UPON A NONPUBLIC UNIVERSITY}

\section{S u m m a r y}

Statute of an University is the manifestation of an autonomy of the latter. It is an intersystemic act that do not contain universally applicable norms because it is addressed to inner circle of recipient. Questions that are normalized by a statute are determined by Law on Higher Education. Authorization to regulate the statute can be mandatory or optional just in case the regulation does not go beyond the scope of the delegation granted. The only accountable subject for the conferral of the first statute to a non-public University is a legal person except for government or local governments. Statute conferral is a powerful privilege for the founder of the university, however, that does not exempt him from compliance with the principle of legality. The first statute of non-public University encompasses not only systemic issues, but also staff and financial matters, and it regulates the area of scientific activity.

Key words: non-public university, statute, statutory matter.

${ }^{81}$ Art. 36 ust. pkt 2 u.p.s.w. 


\section{ПРЕДОСТАВЯЕНИЕ ПЕРВОГО УСТАВА НЕПУБЯИЧНОЙ ВЫСШЕЙ ШКОЛЕ}

\section{P е 3 ю м е}

Устав высшей школы является одним из проявлений автономии вуза. Является актом внутренним, который не содержит общеобязательных норм, потому что адресуется к закрытому кругу адресатов. Представляет акт внутреннего права. Свое закрепление находит в законе «Право о высшем образовании», который казусно обозначает вопросы, переданные к уставному нормированию. Законное полномочие к уставному регулированию может иметь обязательный либо факультативный характер, хотя и в обоих случаях данное регулирование не может нарушать за пределами данной делегации. Предоставление первого устава непубличного вуза является исключительной ее прерогативой основателя - физического либо юридического лица, исключая государственных и юридических лиц местного самоуправления. Предоставление устава является сильным полномочием основателя вуза, однако не освобождает его от соблюдения принципа легализма. Первый устав непубличного вуза охватывает своей дальностью не только вопросы укладов вуза, но также персональные, финансовые дела, а также регулирует сферу научной деятельности.

Ключевые слова: непубличный вуз, устав, уставные материи.

Tłum. na j. rosyjski Michał Mościcki 